\title{
From Krill to Whale: an overview of marine fatty acids and lipid compositions
}

\author{
Michel LINDER \\ Nabila BELHAJ \\ Pascale SAUTOT \\ Elmira Arab TEHRANY

\begin{abstract}
Laboratoire d'ingénierie des biomolécules, Institut National Polytechnique de Lorraine, 2, avenue de la Forêt de Haye, 54505 Vandoeuvre-lès-Nancy $<$ michel.linder@ensaia.inpl-nancy.fr>
\end{abstract}

\begin{abstract}
In this study, fatty acid compositions of phyto-zooplankton (calanoid copepod species, krill...) to fish species (mackerel, sardine anchovy, salmon, shark) are presented. Marine oils are essentially used for their high long-chain polyunsaturated fatty acids (LC-PUFA), namely eicosapentaenoic (EPA) and docosahexaenoic (DHA) for their good health impact. Due to health benefits of the omega-3, weekly fish consumption is today recommended by many authorities (FDA, AFSSA...). Capture fisheries and aquaculture supplied the world with about 110 million tonnes of food fish in 2006 (FAO 2009), providing an apparent per capita supply of $16.7 \mathrm{~kg}$. It is well established that the lipid composition of fish muscle is influenced by the diet and also depends on the effects of environmental factors (temperature, oxygen concentration in sea water) and endogenous medium (physiological state and individual variability). In general, cultured fish have been reported to have a softer texture than wild fish, which has been related to the differences in muscle structure, proximate composition and nutritional value. New applications of typical compounds (wax esters, squalene ...) or lipid classes (glycerophospholipids, ether glycerolipids, sphingophospholipids ...) as cosmetics, functional foods and dietary supplements will become very important in the near future with nano-structured drug carriers in pharmaceutical and biomedical areas.
\end{abstract}

Key words: fatty acids compositions, long-chain polyunsaturated fatty acids (LC-PUFA), EPA, DHA, Krill, fish roes, sharks

generative diseases, and they protect against tumorigenesis. For these reasons, regular fish consumption to provide approximately 200-500 mg per week of EPA and DHA has been recommended by different health organizations. Consequently, these studies led to a strong demand of fish oils and fish oil concentrates on supplement and functional food markets. The need is now so important that the natural resource is declining, leading to the development of aquaculture with the consequence that farmed fish being fed with regular diets, their lipid composition is notably different from wild species, which varies all year long. It is well established that the lipid composition of fish muscle is influenced by the diet and also depends on the effects of environmental factors (temperature and oxygen concentration in sea water) and endogenous medium (physiological state and individual variability). As well known, lipid-rich tissues contain triacylglycerols (TAG) as major lipids, while tissues low in lipid content may be dominated by polar lipids such as phospholipids (PL).

To date, most of the marine living organisms have been investigated for their lipid composition. However, few studies on lipids sources such as PL, glycolipids, alkylglycerols, etc., which may have potentially many benefits over "simple" TAG from fish oils, are undertaken. Several studies on non-conventional marine sources with high contents of LC-PUFAs (microalgae, krill, fish roes...) are now underway.

The purpose of this article is to present an overview of the lipid composition throughout the marine food chain, from the planktonic communities of the world ocean, the large predators, the marine mammals and the world of marine aquaculture.

\section{Lipids from marine sources: structure and composition}

The oceans and adjacent seas have a complex food web including planktivorous and herbivores (krill, salps, copepods) fed upon by birds, fish, squid, seals and baleen whales. Lipids are essential biochemical constituents of all organisms, and lipid composition can often be related to physiology, taxonomy, and can be used to understand and identify food web interactions. Marine oils are much more complex in chemical structure than other oils or fats. They contain many classes of lipids (TAG, PL, hydrocarbons, wax esters, ether-linked compounds...) as well as the diverse group of fatty acids ranging from saturated to highly polyunsaturated. The 
carbon chain length in marine oil fatty acids contain 20, 22 and to a limited extent, 24 carbon atoms, with several double bonds. There are more than 50 different fatty acids present in typical fish oils.

LC-PUFA with 5 and 6 double bonds, namely EPA (C20:5n-3, EPA) and DHA (C22:6n-3, $\mathrm{DHA})$ range in proportion of total fatty acids from $15 \%$ to $30 \%$ in marine oils. Nearly, all the PUFA of marine oils ranging in chain length from $\mathrm{C} 18-\mathrm{C} 22$ are of $\mathrm{n}-3$ with the linolenic acid (LA) as precursor. Figure 1 depicts the chemical structure of polyunsaturated fatty acids, which are usually investigated for their health benefits. Another unusual feature of marine oils is the presence of relatively large amounts of odd carbon chain (mostly C15, C17, C19) and branched fatty acids. Marine oils also contain unsaponifiable matter which varies largely with the species. The presence of sterols is also present in great quantity in fish roes, shellfish and crustaceans. The amount of cholesterol present in fish is lower (under $100 \mathrm{mg} / 100 \mathrm{~g}$ wet fish) than in shellfish and crustaceans (usually 150-200 mg/100 g) (Stansby, 1969). Fatty acids proportion of any given marine species is not constant from fish to fish, but varies depending upon the feed consumed by the fish as well as some other factors (geographical area, season, water temperature, type of feed...).

Omega-3 long-chain fatty acids originate in the lipids of phytoplankton passed up the food chain through zooplankton to the fish. Linoleic acid (18:2) and Linolenic acid (18:3) are considered as essential fatty acids (FA), because they are necessary in the diet for good health and cannot be synthesized by the human organism. Moreover, they are the precursors of LC-PUFA, in particular EPA and DHA. However, a relatively small amount of the precursor ( $\alpha$-linolenic acid) can be converted into EPA and even less to DHA (Hjaltason, 2006).

The beneficial effect of fish consumption on human health has been related, among other factors to the high content of LC-PUFA, which plays very important roles in many aspects of human health disorders, in particular in reducing risks of cardiovascular diseases, hypertension, allergies, and are essential for brain and retina development. The effect of these FA, namely EPA and DHA, is well documented in numerous investigations, as were reviewed (Simopoulos, 1991; Horrocks and Yeo, 1999; Riediger et al., 2009) since the original epidemiological investigations carried out by Bang and Dyerberg (1972) in Eskimos. The consumption of EPA and DHA increased because of the consumer's awareness on health benefits of the omega- 3 fatty acids. Capture fisheries and aquaculture supplied the world with about 110 million tonnes of food fish in 2006 (Data from FAO fisheries and aquaculture 2009) providing an apparent per capita supply of $16.7 \mathrm{~kg}$ (live weight equivalent), which is among the highest on record (table 1).

The natural molecular forms of PUFA are typically TAG and PL. Fatty acid composition and volatile flavour compounds of nine commercial marine oils used in aquaculture have been analyzed by Giogios et al. (2009). This study presents the similarities and differences in FA composition of various oils and the variability of the volatile compounds.

Table 1. World fisheries and aquaculture production and utilization (FAO Fisheries and Aquaculture 2009).

\begin{tabular}{|lrrrrc|}
\hline & $\mathbf{2 0 0 2}$ & $\mathbf{2 0 0 3}$ & $\mathbf{2 0 0 4}$ & $\mathbf{2 0 0 5}$ & $\mathbf{2 0 0 6}$ \\
\hline Production & & & & & \\
\hline INLAND & & & & & \\
\hline Capture & 8.7 & 9.0 & 8.9 & 9.7 & 10.1 \\
\hline Aquaculture & 24.0 & 25.5 & 27.8 & 29.6 & 31.6 \\
\hline Total inland & 32.7 & 34.4 & 36.7 & 39.3 & 41.7 \\
\hline MARINE & & & & & \\
\hline Capture & 84.5 & 81.5 & 85.7 & 84.5 & 81.9 \\
\hline Aquaculture & 16.4 & 17.2 & 18.1 & 18.9 & 20.1 \\
\hline Total marine & 100.9 & 98.7 & 103.8 & 103.4 & 102.2 \\
\hline TOTAL CAPTURE & 93.2 & 90.5 & 94.6 & 94.2 & 92.0 \\
\hline TOTAL AQUACULTURE & 40.4 & 42.7 & 45.9 & 48.5 & 51.7 \\
\hline TOTAL WORLD FISHERIES & 133.6 & 133.2 & 140.5 & 142.7 & 143.6 \\
\hline UTILIZATION & & & & 16.2 & 16.4 \\
\hline Human composition & 100.7 & 103.4 & 104.5 & 107.1 & 110.4 \\
\hline Non-food uses & 32.9 & 29.8 & 36.0 & 35.6 & 33.3 \\
\hline Population (billions) & 6.3 & 6.4 & 6.4 & 6.5 & 6.6 \\
\hline Per capita food fish supply (kg) & 16.0 & 16.3 & 16.2 & 16.4 & \\
\hline
\end{tabular}

$\alpha$-linolenic acid: C18:3 n-3

$9,12,15$-octadecatrienoic acid
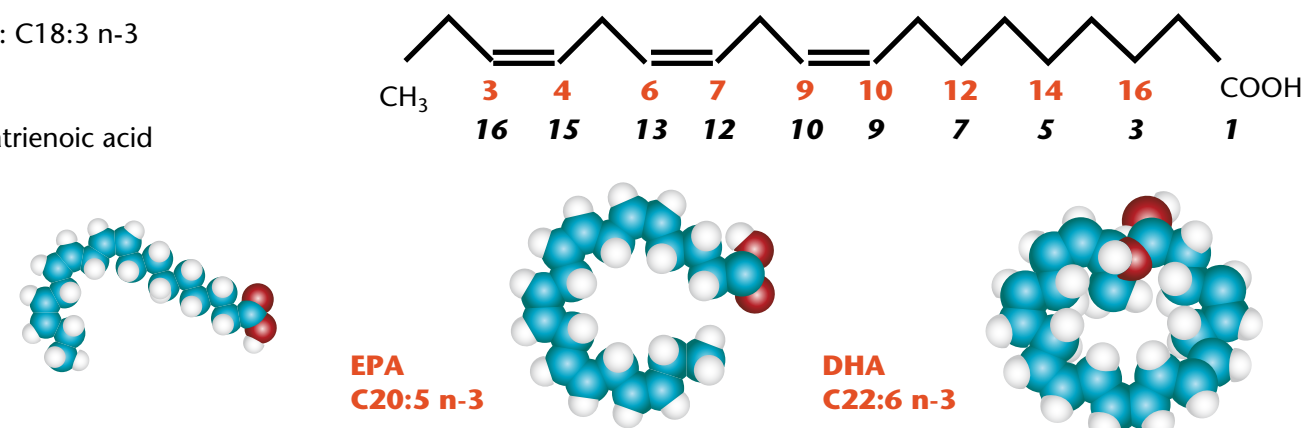

$\alpha$-linolenic acid C18:3 n-3

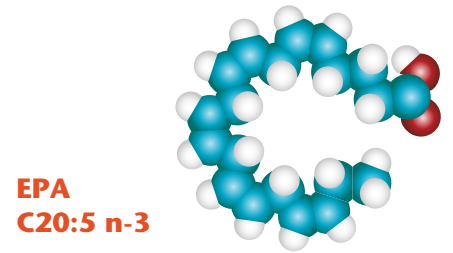

DHA

C22:6 n-3

Figure 1. Structure of the precursor (linoleic acid) and long chain polyunsaturated fatty acids (acid eicosapentaenoic EPA C20:5n-3; acid docosahexaenoic DHA C22:6n-3). 
In fish, LC-PUFAs are mainly located in the $s n-2$ position of the TAG, while saturated fatty acids and monounsaturated fatty acids are located primarily in the $s n-1$ and $s n-3$ position (Ackman, 1980).

Saturated fatty acids (14:0, 16:0 and 18:0) were preferentially esterified in both $s n-1$ and $s n-3$ positions, whereas LC-PUFAs were preferentially located in the $s n-2$ position (Aursand et al., 1995; Ando et al., 1996; Aubourg et al., 1996; Nwosu and Boyd, 1997; Aursand et al., 2000). It is interesting that in the TAG lipids of marine mammals (whale, seal), the sn-2 position is more enriched in saturated fatty acids and LC-PUFA is more located in $s n-1$ and sn-3 position (Brockerhoff et al., 1967; Ackman, 1980).

While TAG is quite homogeneous group of lipids, PL can be divided into three classes: glycerophospholipids, ether glycerolipids and sphingophospholipids. Glycerophospholipids represent the most widespread PL class and can be divided into subclasses according to their polar head, the phosphatidylcholine $(P C)$ is the predominant one.

$\mathrm{PL}$ in fish constitute an important source of health beneficial $n$-3 PUFA (Takahashi, 2004; Falch et al., 2006). Higher levels of EPA and $\mathrm{DHA}$ are concentrated in the PL compared to TAG (Al-Sayed Mahmoud et al., 2008; Belhaj et al., 2010).

Furthermore, use of polar lipids as carriers of $n-3$ PUFAs has received interest, because EPA and $\mathrm{DHA}$ in the $s n-2$ positions are more readily absorbed compared to the TAG, where these fatty acids are in one of the other positions in the molecule (Takahashi, 2004).

\section{Lipids in oceanic zooplankton: a role of feed biomarkers}

Planktonic organisms are characterized by their limited mobility, largely prohibiting a selfdetermined movement against the prevailing ocean currents over longer temporal and spatial scales (Hagen and Auel, 2001). Biodiversity in biomass and plankton abundance are closely related with the seasonal oscillation, light intensity, temperature and depth. The herbiv- orous organisms, the calanoid copepod species and krill (Euphausiacea), synthesize large amount of wax esters with long-chain monounsaturated fatty acids (C22) and alcohols as high-efficiency energy reserve (table 2). Plankton accumulates lipid reserves as wax esters, in order to withstand long periods of starvation and to provide the buoyancy in the water column. There is general agreement that phytoplanktons are the major source of essential fatty acids in the marine environment and the ratio of typical fatty acids can be used as biomarkers for different classes of phytoplanktons (Alkanani et al., 2007). Specific trophic biomarkers, typical of phytoplankton or zooplankton, have been used because of their incorporation without modification into neutral lipid of the predator. For instance, fatty acids such as C16:1 (n-7) or EPA are typical markers of diatoms, whereas DHA or C18:4 (n-3) occurs in dinoflagellates. Copepod species are targeted by $\mathrm{C} 20: 1$ and C22:1 fatty acids.

Smaller phytoplankton species such as pennate diatoms and flagellates contain significant amounts of LC-PUFA, especially EPA and DHA, as well as 16:0, 16:1 $107,14: 0$ and the diatom marker 16:401 (Parrish et al., 1991). Larger phytoplankton such as dinoflagellates also con-

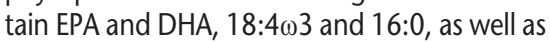
the uncommon 18:503 fatty acids (Leblond and Chapman, 2000). Table 3 showed the FA composition of phytoplankton with high amounts of $16: 0,22: 6 \omega 3,20: 5 \omega 3,14: 0$, $16: 1 \omega 7$ and $18: 0$, but usually high percentages of 18:1 109 and C20-NMIDs (non-methyleneinterrupted dienoic). This 20:2NMIDs fatty acid group may have an important metabolic or structural function. The pathways for the biosynthesis of these fatty acids in molluscs have been established and involved the insertion of a double bond at the $5^{\text {th }}$ position to form 20:2-5,13 and 20:2-5,11.

As in phytoplankton, PUFA was the major component of the identified fatty acids in mussels. The role of PUFA may be important in many different development stages of mussels due to their limited ability to synthesize 20:5 13 and 22:603 (Alkanani et al., 2007).
The biomass of Antarctic krill is the most abundant animal species on Earth and paradoxically, one of the least exploited marine resources in the world (the standing stock biomass is estimated: 650 million metric tonnes). An estimated 150 million metric tonnes per year were consumed by birds, fish, squid, seals and baleen whales (Watkins, 2007). E. superba provides 30\%-90\% of the diet for these carnivores (Phleger et al., 1998). Among 85 different species of small planktonic crustaceans known

Table 3. Fatty acid composition (\%) in phytoplankton from Fortune Harbour and Charles Arms sites (adapted from Alkanani et al., 2007).

\begin{tabular}{|lc|}
\hline Fatty acid & Phytoplankton \\
\hline $14: 0$ & 7.41 \\
\hline i15:0 & 1.17 \\
\hline $15: 0$ & 1.45 \\
\hline $16: 0$ & 24.67 \\
\hline $16: 1 n-7$ & 5.05 \\
\hline $18: 0$ & 4.57 \\
\hline $18: 1 n-9$ & 4.87 \\
\hline $18: 1 n-7$ & 2.90 \\
\hline $18: 2 n-6$ & 1.42 \\
\hline $18: 3 n-3$ & 1.27 \\
\hline $18: 4 n-3$ & 2.24 \\
\hline $20: 1 n-11$ & 0.23 \\
\hline $20: 1 n-9$ & 1.56 \\
\hline $20: 2 N M I D$ & 0.57 \\
\hline $22: 2 N M I D$ & 0.11 \\
\hline $20: 4 n-6$ & 0.64 \\
\hline $20: 5 n-3$ & 9.28 \\
\hline $22: 5 n-3$ & 0.41 \\
\hline $22: 6 n-3$ & 14.97 \\
\hline
\end{tabular}

NMID FA: Non-Methylene-Interrupted Dienoic FA.

Table 2. Lipid data of several calanoid copepod from the Antarctic Weddell Sea (modified after Hagen and Auel, 2001). DM: dry mass.

\begin{tabular}{|llllll|}
\hline Characteristics & Calanoides acutus & Rhincalanus gigas & Calanus propinquus & Metridia gerlachei & Pareuchaeta antarctica \\
\hline Maximum size $(\mathrm{mm})$ & 5 & 8 & 5 & 4 & 9 \\
\hline Maximum lipid content & $51 \%$ DM & $33 \%$ DM & $56 \%$ DM & $44 \%$ DM & $45 \%$ DM \\
\hline Major storage lipid & Wax esters & Wax esters & triacylglycerols & Wax esters/triacylglycerols & Wax esters \\
\hline Typical fatty acids & $20: 1 ; 22: 1$ & $16: 1 ; 18: 1 ; 18: 4$ & $22: 1(2$ isomers $)$ & $16: 1 ; 18: 1$ & $16: 1 ; 18: 1$ \\
\hline Typical fatty alcohols & $20: 1 ; 22: 1$ & $14: 0 ; 16: 0$ & - & $14: 0 ; 16: 0$ & $14: 0 ; 16: 0$ \\
\hline
\end{tabular}


as euphausiids, six species have been fished and they have a potential commercial interest. The "Antarctic krill" Euphausia superba, a species contributing essentially to the biomass in Antarctic waters, is subject to significant commercial fishing. Krill oil is gaining increasing attention from nutraceutical and functional food due to its three main quality attributes: the omega- 3 fatty acids as well as PL. It is also a rich source of astaxanthin, carotenoid pigment and powerful antioxidant. E. superba, E. tricantha and $E$. frigid were also characterized by relatively high percentage of TAG with high level of PUFA. This lipid class also appears as the major energy storage in several Antarctic copepods, which could represent potential diets (Ju and Harvey, 2004). EPA and DHA were the two major unsaturated fatty acids (table 5). TAG is the main lipid deposits, but polar lipids such as PL, namely phosphatidylcholine, are also accumulated. PL were the major lipid class in most of the zooplankton (tables 4, 6). Hagen et al. (1996) have suggested that even PL also might serve as storage lipids for $E$. superba and E. crystallorophias. Moreover, Euphausia crystallorophias and Thysanoessa macrura, in contrast to $E$. superba, synthesize primarily wax ester as energy reserve (Hagen and Auel, 2001). Even though a diverse suite of sterols were present, cholesterol remained the major sterol (more than $76 \%$ of total sterols) in all krill, with a minor variation between species (Phleger et al., 1998; Ju and Harvey, 2004). Moreover, krill contains potent proteolytic and lipolytic enzymes, and high levels of free fatty acids can occur where sufficient care is not taken in handling and processing samples.

Zooplankton biomass represents the favourite diet of whales which can swallow up to 4 tonnes of krill per day. These microscopic crustaceans provide a significant crude lipid source for these marine mammals required during migrations. Budge et al. (2008) have studied the blubber fatty acid composition of bowhead whales (Balaena mysticetus) to evaluate the implications for diet assessment and ecosystem monitoring. FA compositions of bowhead whales were characterized by typical marine FA, and were dominated by 14:0, 16:0, 16:1n-7, 18:0, 18:1n-9, 18:1n-7, 20:1n-11, 20:1n-9, $22: 1 n-11,22: 1 n-9,20: 5 n-3,22: 5 n-3$ and $22: 6 n-3$, which depend on the phytoplankton fatty acid signature (table 7). Whale oil derived from the blubber is typically low in omega-3 LC-PUFA. Several studies (in Budge et al. article, 2008) showed that vertical stratification of FA composition in blubber has been reported. A higher monounsaturated FA amount (14:1n-5, 16:1n-7, 18:1n-9) and lower saturated $F A(16: 0,18: 0)$ were observed in the outer in contrast to the inner blubber layers. This particular arrangement of FA might enhance membrane fluidity in the outer blubber layers and improves the insulation properties of the blubber. Moreover, researches focus on the potential to use bowhead blubber FA to monitor ecological change at the base of the food web that is driven by climate variation.

Several studies have investigated the relationship between lipid content/fatty acid compositions and season of catch. Zlatanos and Laskaridis (2007) have studied the influence of seasonality on the fat content and the fatty acid composition of the sardine (Sardina pilchardus), the anchovy (Engraulis encrasicholus) and the picarel (Spicara smaris), in order to find

the best source of $n-3$ fatty acids during the year. Table 8 adapted from the aforementioned authors showed that fish lipid content depends on season, fish life cycle, external factors like temperature, salinity and fatty acid composition of their food. The fat content of the sardine was minimal at the end of winter and maximal at the end of spring. On the other hand, the fat content of the anchovy and the picarel was maximal at the end of winter - beginning of spring and minimal at the end of the summer.

Jensen et al. (2007) have studied the variations of fatty acid composition of herring (especially the variation in EPA and DHA) on a large

Table 4. Composition of lipid classes from Southern Ocean zooplankton (adapted from Phleger et al., 1998).

\begin{tabular}{|lccccc|}
\hline & TAG & FFA & Sterols & PL & $\begin{array}{l}\text { Lipids } \\
\mathbf{m g} / \mathbf{g}\end{array}$ \\
\hline E. superba & 37.3 & 0.0 & 4.1 & 58.2 & 29.5 \\
\hline E. tricantha & 54.2 & 1.0 & 1.0 & 36.3 & 3.2 \\
\hline E. frigida & 27.2 & 0.7 & 3.1 & 69.1 & 15.8 \\
\hline
\end{tabular}

Table 5. Composition of fatty acids (\% of total fatty acid) in Antarctic Euphausiids (adapted from Ju and Harvey, 2004).

\begin{tabular}{|lccc|}
\hline Fatty acids & Euphausia superba & Euphausia tricantha & Euphaudia frigida \\
\hline $14: 0$ & 1.2 & 0.6 & 0.9 \\
\hline $16: 0$ & 16.2 & 13.4 & 18.0 \\
\hline $16: 1 \mathrm{n}-7$ & 1.3 & 1.5 & 2.2 \\
\hline $18: 0$ & 1.2 & 5.6 & 5.9 \\
\hline $18: 1 \mathrm{n}-9$ & 5.9 & 17.7 & 15.3 \\
\hline $18: 1 \mathrm{n}-7$ & 8.0 & 10.5 & 12.9 \\
\hline $18: 2 \mathrm{n}-6$ & 0.6 & 1.8 & 2.2 \\
\hline $20: 1 \mathrm{n}-9$ & 0.3 & 9.5 & 3.1 \\
\hline $20: 5 \mathrm{n}-3$ & 31.6 & 6.7 & 10.9 \\
\hline $22: 6 \mathrm{n}-3$ & 28.3 & 15.8 & 18.1 \\
\hline
\end{tabular}

Table 6. Lipid data of the dominant Euphausiid species in the Antarctic (modified after Hagen and Auel, 2001) DM: dry mass.

\begin{tabular}{|llll|}
\hline Characteristics & Euphausia superba & $\begin{array}{l}\text { Euphausia } \\
\text { crystallorophias }\end{array}$ & Thysanoessa macrura \\
\hline Maximum size $(\mathrm{mm})$ & 56 & 41 & 33 \\
\hline Maximum lipid content & $46 \% \mathrm{DM}$ & $52 \% \mathrm{DM}$ & $56 \% \mathrm{DM}$ \\
\hline Major storage lipid & $\begin{array}{l}\text { Triacylglycerols } \\
\text { phosphatidylcholine }\end{array}$ & $\begin{array}{l}\text { Wax esters } \\
\text { phosphatidylcholine }\end{array}$ & $\begin{array}{l}\text { Wax esters } \\
\text { phosphatidylcholine }\end{array}$ \\
\hline Typical fatty acids & $14: 0 ; 16: 0 ; 18: 1$ & $16: 0 ; 18: 1$ & $14: 0 ; 16: 0 ; 18: 1$ \\
\hline Typical fatty alcohols & none & $14: 0 ; 16: 0$ & $18: 1 ; 20: 1$ \\
\hline
\end{tabular}


Table 7. Variation of fatty acid proportions in blubber layers in bowhead Whales Balaena mysticetus (adapted from Budge et al., 2008).

\begin{tabular}{|c|c|c|}
\hline Fatty acids & Inner & outer \\
\hline $10: 0$ & 0.36 & 0.08 \\
\hline $14: 0^{a}$ & 4.34 & 4.13 \\
\hline $\mathrm{i}-15: 0$ & 0.12 & 0.12 \\
\hline $15: 0$ & 0.24 & 0.23 \\
\hline $16: 0^{a}$ & 11.30 & 8.89 \\
\hline $\mathrm{i}-17: 0$ & 0.12 & 0.10 \\
\hline $17: 0$ & 0.15 & 0.11 \\
\hline $18: 0^{a}$ & 2.91 & 1.69 \\
\hline Subtotal & 19.55 & 15.35 \\
\hline $14: 1 n-9$ & 0.27 & 0.14 \\
\hline $14: 1 n-5^{a}$ & 0.19 & 0.63 \\
\hline $16: 1 n-11$ & 0.37 & 0.40 \\
\hline $16: 1 n-9$ & 0.22 & 0.23 \\
\hline $16: 1 n-7^{a}$ & 13.75 & 19.31 \\
\hline $17: 1 n-8$ & 0.13 & 0.20 \\
\hline $18: 1 n-11$ & 2.38 & 2.05 \\
\hline $18: 1 n-9^{a}$ & 11.63 & 13.24 \\
\hline $18: 1 n-7^{a}$ & 4.10 & 5.32 \\
\hline $18: 1 n-5$ & 0.60 & 0.58 \\
\hline 20:1n-11 & 2.69 & 2.14 \\
\hline $20: 1 n-9^{a}$ & 11.19 & 8.42 \\
\hline $20: 1 n-7$ & 1.72 & 1.34 \\
\hline $22: 1 n-11^{a}$ & 5.00 & 5.67 \\
\hline $22: 1 n-9$ & 1.5 & 1.07 \\
\hline $22: 1 n-7$ & 0.31 & 0.27 \\
\hline $24: 1 n-9$ & 0.19 & 0.10 \\
\hline Subtotal & 56.24 & 61.13 \\
\hline $16: 3 n-6$ & 0.61 & 0.73 \\
\hline $16: 3 n-4$ & 0.24 & 0.20 \\
\hline $16: 4 n-1$ & 0.35 & 0.29 \\
\hline $18: 2 n-6$ & 0.69 & 0.66 \\
\hline $18: 2 n-4$ & 0.13 & 0.17 \\
\hline $18: 3 n-6$ & 0.15 & 0.12 \\
\hline $18: 3 n-4$ & 0.25 & 0.27 \\
\hline $18: 3 n-3$ & 0.31 & 0.34 \\
\hline
\end{tabular}

\begin{tabular}{|lcc|}
\hline Fatty acids & Inner & outer \\
\hline $18: 4 n-3$ & 0.82 & 0.65 \\
\hline $18: 4 n-1$ & 0.35 & 0.43 \\
\hline $20: 2 n-6$ & 0.15 & 0.17 \\
\hline $20: 4 n-6$ & 0.30 & 0.32 \\
\hline $20: 4 n-3$ & 0.44 & 0.43 \\
\hline $20: 5 n-3^{a}$ & 7.40 & 9.40 \\
\hline $21: 5 n-3$ & 0.44 & 0.34 \\
\hline $22: 5 n-3^{a}$ & 3.68 & 3.03 \\
\hline $22: 6 n-3^{a}$ & 6.19 & 4.30 \\
\hline Subtotal & 22.49 & 21.86 \\
\hline
\end{tabular}

${ }^{a}$ Indicates FA used to assess extent of stratification.

numbers of individuals caught. The lipid content and the fatty acid composition of the different catches summed up for PUFA, MUFA and SFA are shown in figure 2. Total lipid content varied significantly among catches, with the highest amount during summer for herring. The seasonal variation in lipids is ascribed to the lack of feeding during the winter. This high EPA content found only in herring caught in May 2003 is related to variation in the fatty acid composition of the copepods on which the herring feed.

However, these seasonal lipid variation affects not only fish species with greater richness in oil considered traditionally to be "blue" (fatty), but also the fish species commonly considered to be "white" (little fat). Soriguer et al. (1997a) have investigated the composition in lipids of 35 common fish species in Spain (table 9). The conclusions of this study showed important differences in fat concentration of the species studied.

It is therefore very important from a nutritional point of view to take into account the lipid content and the fatty acid composition which may influence the quality and functional properties of the processed products. Soriguer et al. (1997b) reported the extreme case of the mackerel (S. scombrus) which, between spring and winter, may increase its lipid composition eight folds in percentage terms.
Fish species like sardine, anchovy and mackerel are rich sources of LC-PUFA, and therefore, they are recommended as part of a diet aiming at improving the intake of these fatty acids (Zlatanos and Laskaridis, 2007; Jensen et al., 2007). Although, the recommended intake varies with the different associations (American Heart Association, Food and Drug Administration, International Society for the Study of Fatty Acids and Lipids), most recommendations are in the range of $0.5-1.0 \mathrm{~g}$ $E P A+D H A$ day ${ }^{-1}$ for adults (250 mg DHA and $250 \mathrm{mg} \mathrm{EPA} \mathrm{day}^{-1}$ according to AFSSA, 2010). A survey of the nutritional composition of fish and seafood purchased and consumed by French population was conducted by Sirot et al. (2008). A total of 159 fish, mollusc and crustacean samples were collected in four French coastal areas and analyzed for total lipids and fatty acids, especially n-3 LC-PUFA. Results showed that eel, salmon, swordfish and halibut are the richest fish in total lipids and n-3 LC-PUFA, with average levels of 20.4, 13.5 , 12.4 and $11.7 \mathrm{~g}$ lipids $/ 100 \mathrm{~g}$ fresh edible portion, respectively.

In the world, the ten species that contributed most to global catches represent more than $30 \%$ of the total global marine catch in 2006 (figure 3). This group of species consists of five small pelagic species (anchoveta, Atlantic herring, chub, Chilean jack mackerels and Japanese anchovy), two tunas (skipjack and yellowfin), two low-value gadiformes (Alaska pollock and blue whiting) that are mostly marketed in processed forms, and the largehead hairtail, a bentho-pelagic species (FAO Fisheries and Aquaculture, 2009).

We observe a considerable variation of fatty acid composition of fish oils between different fish species. Table 10 and table 11 showed the fatty acid composition of several investigated fish species with low and high amount of PUFA (data adapted from numerous authors). It is well established for various fish species that the fatty acid composition is influenced by variations in the feed available for the species, water temperature, sexual status, size or age of animals affecting metabolic activity (Médale, 2009; Robin et al., 2003). However, the use of vegetable oils in fish diets has an influence on flesh quality and considering the interest in fish n-3 fatty acids for human health, fatty acid pro-

Table 8. Fat contents ( $\mathrm{g} / 100 \mathrm{~g}$ dry sample) of sardine (Sardina pilchardus), anchovy (Engraulis encrasicholus) and the picarel (Spicara smaris) (data adapted from Zlatanos and Laskaridis, 2007).

\begin{tabular}{|llllllll|}
\hline & February & April & June & August & October & December & Mean \\
\hline Sardine & $3.88 \pm 0.2$ & $11.86 \pm 0.6$ & $11.47 \pm 0.5$ & $5.88 \pm 0.2$ & $8.46 \pm 0.5$ & $6.92 \pm 0.2$ & 8.08 \\
\hline Anchovy & $5.71 \pm 0.4$ & $3.41 \pm 0.3$ & $1.32 \pm 0.2$ & $0.94 \pm 0.2$ & $2.99 \pm 0.3$ & $2.85 \pm 0.2$ & 2.87 \\
\hline Picarel & $4.42 \pm 0.4$ & $4.52 \pm 0.3$ & $2.95 \pm 0.2$ & $0.93 \pm 0.2$ & $1.85 \pm 0.3$ & $3.06 \pm 0.3$ & 2.96 \\
\hline
\end{tabular}




\begin{tabular}{|lcccc|}
\hline & & \multicolumn{2}{c}{ PUFA } \\
\cline { 3 - 4 } Catch & Number of herring & EPA & DHA & Lipid \\
\hline NSE-Jul-01 & 26 & $6.9 \pm 0.2$ & $11.0 \pm 0.4$ & $16.0 \pm 0.9$ \\
S-Jul-01 & 193 & $6.5 \pm 0.1$ & $10.0 \pm 0.1$ & $16.9 \pm 0.3$ \\
K-Jul-01 & 33 & $6.8 \pm 0.3$ & $11.0 \pm 0.5$ & $14.0 \pm 0.9$ \\
NSW-Aug-01 & 61 & $6.1 \pm 0.2$ & $10.6 \pm 0.2$ & $15.6 \pm 0.5$ \\
BS-Nov-01 & 58 & $6.1 \pm 0.1$ & $10.9 \pm 0.1$ & $12.7 \pm 0.3$ \\
BS-Mar-02 & 56 & $5.1 \pm 0.1$ & $9.6 \pm 0.2$ & $9.5 \pm 0.4$ \\
NSE-Jun-02 & 39 & $7.0 \pm 0.2$ & $11.5 \pm 0.5$ & $12.9 \pm 0.8$ \\
NSE-Jul-02 & 19 & $7.8 \pm 0.4$ & $13.8 \pm 1.3$ & $9.6 \pm 1.1$ \\
S-Jul-02 & 157 & $6.4 \pm 0.1$ & $10.3 \pm 0.2$ & $14.6 \pm 0.3$ \\
K-Jul-02 & 40 & $6.4 \pm 0.1$ & $10.0 \pm 0.2$ & $15.4 \pm 0.5$ \\
NSW-Sep-02 & 57 & $5.8 \pm 0.1$ & $10.2 \pm 0.2$ & $10.1 \pm 0.4$ \\
NSN-Nov-02 & 50 & $5.4 \pm 0.1$ & $11.0 \pm 0.4$ & $6.5 \pm 0.4$ \\
NSN-Feb-03 & 50 & $4.4 \pm 0.2$ & $13.1 \pm 0.6$ & $4.5 \pm 0.3$ \\
K-Feb-03 & 50 & $4.5 \pm 0.1$ & $9.5 \pm 0.4$ & $7.9 \pm 0.4$ \\
NSN-May-03 & 48 & $11.0 \pm 0.3$ & $11.9 \pm 0.3$ & $6.9 \pm 0.3$ \\
\hline
\end{tabular}

Figure 2. Fatty acid composition of herring (Clupea harengus L.): influence of time and place of catch on n-3 PUFA content (adapted from Jensen et al., 2007).

file of fish fed plant oils might be considered as having possible negative effects in this regard. Despite the "washout" period to return to values similar to those of fish continuously fed, several studies showed that some differences still remained among experimental groups (Polvi and Ackman, 1992; Robin et al., 2003; Nanton et al., 2007). The functional nutritional value of these modified products is thereby reduced, linking alternative lipids with reductions in the nutritional benefit of consuming fillets from cultured fish. To mitigate conflicting demands of sustainability and product value, the implementation of "finishing diets" at the end of the production cycle to restore LC-PUFA content was used leading to a partial

Table 9. "Blue» or "White» fish species: a lipid composition depending on the seasons (adapted from Soriguer et al., 1997).

\begin{tabular}{|llll|}
\hline Name & $\begin{array}{l}\text { Lipids } \\
\text { (in g/100 } \\
\text { of wet } \\
\text { muscle } \\
\text { tissue) }\end{array}$ & $\begin{array}{l}\mathbf{n - 3} \\
\mathbf{( \% )}\end{array}$ & $\begin{array}{l}\mathbf{n - 6} \\
\mathbf{( \% )}\end{array}$ \\
\hline Dover sole & $0.7-1.8$ & $21.5-34.6$ & $3.8-5.4$ \\
\hline Turbot & $0.7-1.1$ & $35.1-39.2$ & $4.0-4.2$ \\
\hline Tuna & $0.9-1.4$ & $13.0-35.6$ & $3.8-4.5$ \\
\hline Anchovy & $2.6-4.3$ & $35.6-43.3$ & $2.6-3.3$ \\
\hline Mackerel & $\mathbf{1 . 8 - 1 7 . 2}$ & $14.4-38.3$ & $2.7-4.9$ \\
\hline European eel & $8.4-9.0$ & $7.8-9.5$ & $7.3-7.9$ \\
\hline Bass & $0.6-3.0$ & $20.2-30.0$ & $2.8-3.9$ \\
\hline Shrimp & $0.5-1.0$ & $26.0-35.5$ & $6.1-12.8$ \\
\hline
\end{tabular}

bass can be considered as a good source of the $\mathrm{n}-3$ series fatty acids, particularly of EPA and DHA, showing the highest levels in wild specimens (table 12). Moreover, higher fat levels in farmed fish (4.4/100 g) compared to wild fish $(1 \mathrm{~g} / 100 \mathrm{~g})$ have also been observed due to the use of commercial diets usually higher in fat content and more reduced activity for the cultured fish (Fuentes et al., 2010).

Capture fisheries and aquaculture supplied the world with about 110 million tonnes of food fish (FAO Fisheries and Aquaculture, 2009). Of this total, aquaculture accounted for $47 \%$ and more than 110 million tonnes $(77 \%)$ of world fish production was used for direct human consumption in 2006. Most industrial fish oil is now used in aquaculture as part of the feed for farmed fish, with close to $85 \%$ of production consumed by the sector, and with salmonids responsible for more than $55 \%$ of the sector's share (FAO, 2009). Demand for fish oil for direct human use is boosting prices. In early 2008, fish oil prices soared to an all-time record of US\$1 700/tonne, compared with US $\$ 915 /$ tonne one year earlier (FAO, 2009).

restoration of fillet LC-PUFA content (Lane et al., 2006).

In general, cultured fish have been reported to have a softer texture and milder flavour than wild fish, which has been related to differences in muscle structure, proximate composition and the aromatic compounds profile (Fuentes et al., 2010). They investigated the chemical composition, nutritional value and physicochemical parameters of sea bass ( $D$. labrax) from different geographical areas of Spain and from aquaculture and wild origin.

The saturated fatty acids and polyunsaturated fatty acids were higher in wild sea bass, whereas farmed specimens showed a higher content of monounsaturated fatty acids. Sea
The aquaculture sector consumed about 3.06 million tonnes (or $56.0 \%$ ) of world fishmeal production and 0.78 million tonnes (or $87.0 \%$ ) of total fish oil production in 2006, where more than $50 \%$ goes into salmonid diets. Other fishery products used in the production of aquafeeds are krill meal, squid meal, squid liver powder, squid oil, shrimp meal and crab meal. The total amount of fishmeal and fish oil used in aquafeeds is estimated to have grown more than three folds between 1992 and 2006 (The State of World Fisheries and Aquaculture, 2008, FAO Fisheries and Aquaculture, 2009).

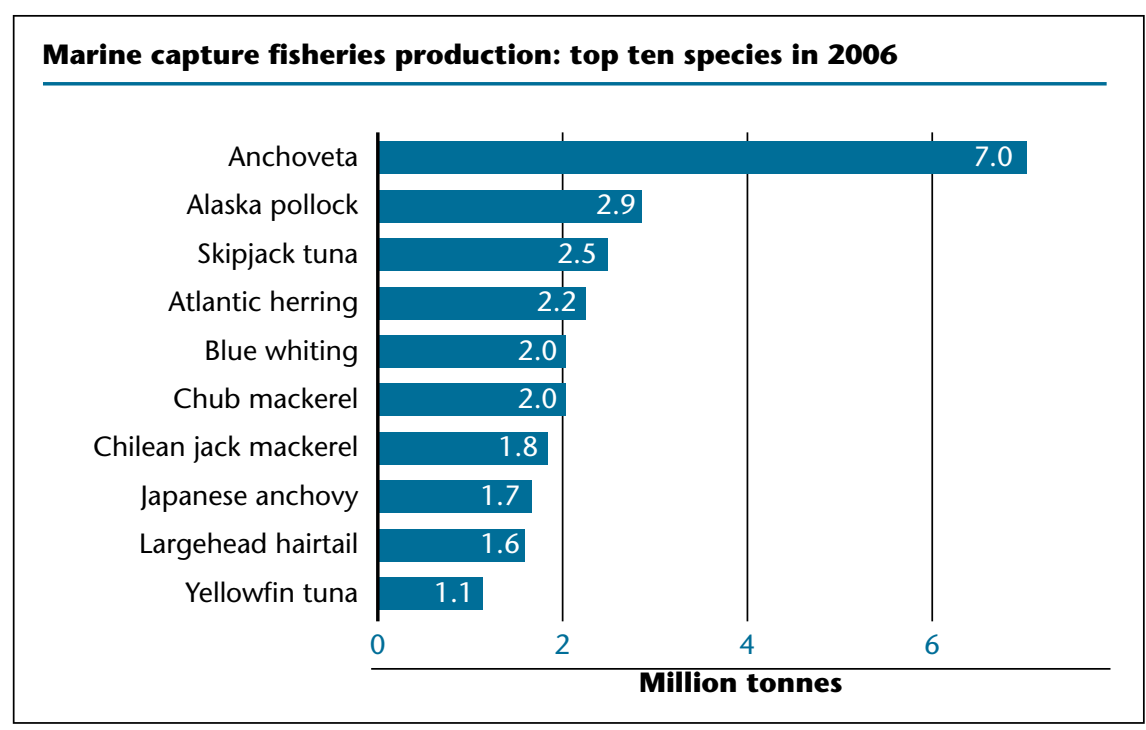

Figure 3. The State of World Fisheries and Aquaculture 2008 (FAO Fisheries and Aquaculture, 2009). 
Table 10. Fatty acid composition of several investigated fish species adapted from different source.

\begin{tabular}{|c|c|c|c|c|c|c|c|c|}
\hline Fatty acids & $\begin{array}{l}\text { Turbot (Psetta } \\
\text { maxima) } \\
\text { (a) }\end{array}$ & $\begin{array}{l}\text { Menhaden } \\
\text { (b) }\end{array}$ & $\begin{array}{l}\text { Mackerel } \\
\text { (c) }\end{array}$ & $\begin{array}{l}\text { Mackerel } \\
\text { (d) }\end{array}$ & $\begin{array}{l}\text { Herring } \\
\text { (mean value) } \\
\text { (e) }\end{array}$ & $\begin{array}{l}\text { menhaden } \\
\text { (f) }\end{array}$ & $\begin{array}{l}\text { Seal } \\
\text { (c) }\end{array}$ & $\begin{array}{l}\text { Whale muscle } \\
\text { (c) }\end{array}$ \\
\hline $14: 0$ & 6.9 & 11.3 & 5.1 & 5.3 & 6.2 & 7.6 & 5.0 & 2.6 \\
\hline 15:0 & - & 0.7 & - & 0.6 & - & 0.6 & - & \\
\hline $16: 0$ & 14.4 & 21.3 & 12.6 & 19.4 & 11.6 & 19.2 & 11.3 & 15.3 \\
\hline $16: 1 n-7$ & & 12.6 & 8.1 & 4.5 & 3.8 & 10.4 & - & 5.7 \\
\hline 18:0 & 1.5 & 3.5 & 2.6 & 4.9 & 1.0 & 3.54 & 1.1 & 5.7 \\
\hline 18:1n-9 & 5.9 & 10.4 & 12.3 & 13.9 & 7.2 & 12.3 & 22.3 & 38.8 \\
\hline 18:1n-7 & 2.6 & & - & - & 1.3 & - & 4.9 & 4.0 \\
\hline $18: 2 n-6$ & 5.3 & 1.5 & 1.5 & 1.9 & 1.6 & 1.3 & 1.1 & 1.1 \\
\hline $18: 3 n-3$ & 1.2 & 1.4 & 1.1 & 2.3 & 1.3 & 1.2 & - & - \\
\hline $18: 4 n-3$ & 2.2 & 3.3 & 2.0 & - & 3.5 & 2.3 & - & - \\
\hline $20: 1 n-9$ & 9.2 & 1.0 & 7.2 & 4.4 & 12.5 & 2.0 & - & 6.1 \\
\hline $20: 4 n-6$ & 0.4 & 1.3 & - & 1.7 & - & 2.1 & - & - \\
\hline $20: 5 n-3$ & 6.8 & 14.1 & 6.1 & 8.7 & 6.3 & 12.0 & 6.6 & 0.9 \\
\hline $22: 1 n-11$ & 11.3 & - & - & - & 21.5 & - & 2.3 & 2.2 \\
\hline $22: 5 n-3$ & 1.8 & 2.8 & - & 1.3 & - & 3.0 & 4.4 & 0.7 \\
\hline $22: 6 n-3$ & 11.1 & 14.4 & 7.0 & 15.9 & 10.6 & 8.4 & 8.7 & \\
\hline
\end{tabular}

a) Robin et al. (2003); b) Lyberg and Adlercreutz P. (2008); c) Sébédio et al. (1993); d) Soriguer et al. (1997a,b); e) Jensen et al. (2007); f) Liu et al. (2004).

Due to the general decline of fish stocks, the investigation of unfished or less-exploited fish species is needed, and a better use of raw material is required, involving the evaluation of by-products from fisheries. Vall Ould El Kebir et al. (2007) investigated the complete fatty acid composition from some Elasmobranchs species which seems to be still neglected, such as rays. It is well known that the liver of ray fishes is rich in poly and highly unsaturated fatty acids. Ray fish liver oil may have applications in aquacultural feed manufacturing and other industries, taking into account that over 6,000 tonnes of ray fishes are caught in Mexico each year (Perez-Velazquez, 2008). Table 13 adapted from Vall Ould El Kebir et al. (2007) showed the high amounts of essential PUFA, specially DHA in muscle, liver and gonad of rays which can be used for direct human nutrition or the food processing industry.

Fish oil may also be extracted from salmon heads, rich in LC-PUFA, by enzymatic process and could be used in nutraceutical domain due to the high level of polar lipids (Linder et al., 2005; Belhaj et al., 2010).

Considerable data are available on lipids and fatty acid compositions in shark tissues, mainly centered on liver oil, which contained high levels of DHA (Navarro-Garcla et al., 2000) (table 14). The liver oil of many deep-sea sharks contains several uncommon, low-density lipid classes, chiefly squalene (density $0.86 \mathrm{~g} \mathrm{~mL}^{-1}$ ) and diacyl glyceryl ether (density $0.89 \mathrm{~g} \mathrm{~m}^{-1}$ ) participating in the buoyancy of the animal (Wetherbee and Nichols, 2000). The incorporation of squalene hydrogenated into squalane in pharmaceutical products enhances skin absorption of cosmetics and medicaments. Studies on pelagic shark species revealed that the liver lipids contained high levels of n-3 PUFA, especially DHA (up to 25\%). Depending on the shark species, the oil can be rich in 1-0-alkylglycerols, which exhibit bacteriostatic and fungistatic properties, anti-inflammatory activities and a hemopoietic effect (Navarro-Garcia et al., 2000).

\section{Fish eggs: \\ a source of LC-PUFAs}

For their nutritional and sensorial values, fish roe products are widely consumed throughout the world and can be considered as an interesting valuable source of PUFA. Many studies have highlighted the extreme variability of fish roe's composition in water, protein and lipid content due to several factors like fish species, develop- mental stage, environment, season and diets (Al-Sayed Mahmoud et al., 2008). Roe yield (wt\%) differs from fish species to another; it can be ranged from $6 \%$ in mackerel fish (Scomber japonicus), 10\% in chinook salmon (Oncorhynchus tshawytscha), 20\% in white sturgeon (Acipenser transmontanus), up to $26 \%$ in carp (Cyprinus sp.). The physicochemical composition of salted and dried mullet roes (Mugil cephalus) known as "bottarga" was investigated by Scano et al. (2008).

An average lipid content of $270 \mathrm{mg} / \mathrm{g}$ of the edible portion for bottarga sample was measured. Total cholesterol was measured as mean content of 9.3 and $10.5 \mathrm{mg} / \mathrm{g}$ of edible product and represented ca. 3\%-4\% of total lipids. Cholesterol content of Oncorhynchus mykiss roe was about $3.5 \%$ of total lipids, compared to higher contents observed in white seabream (Diplodus sargus) $11.4 \%$, cod (Gadus morhua) 8.7\%, atlantic salmon (S. salar) $5.2 \%$, and herring (Clupea harengus) $8.3 \%$. However, oil egg may be extracted by enzymatic process and contained about half of the total cholesterol amount, due to the tensionactive properties of polar lipids partially retained in the heavy fraction (Al-Sayed Mahmoud et al., 2008). The composition of fatty acids present in the bottarga product is 
Table 11. Fatty acid composition of several investigated fish species adapted from different source.

\begin{tabular}{|c|c|c|c|c|c|c|}
\hline Fatty acids & $\begin{array}{l}\text { Sardina Pilchardus } \\
\text { (a) }\end{array}$ & $\begin{array}{l}\text { Anchovy (Engraulis } \\
\text { encrasicholus) } \\
\text { (a) }\end{array}$ & $\begin{array}{l}\text { Tuna } \\
\text { (c) }\end{array}$ & $\begin{array}{l}\text { Pacific bluefin } \\
\text { tuna } \\
\text { (d) }\end{array}$ & $\begin{array}{l}\text { Squid oil } \\
\text { (e) }\end{array}$ & $\begin{array}{l}\text { Crude sardine oil } \\
\text { (f) }\end{array}$ \\
\hline $14: 0$ & 7.0 & 6.8 & 3.9 & 2.9 & 5.7 & 6.34 \\
\hline 15:0 & 0.9 & 1.1 & & 0.4 & 0.6 & - \\
\hline $16: 0$ & 23.2 & 27.1 & 17.6 & 17.8 & 22.8 & 22.2 \\
\hline $16: 1 n-7$ & 6.1 & 4.2 & 5.4 & 3.7 & 4.2 & 9.58 \\
\hline 18:0 & 3.3 & 5.2 & 4.1 & 6.2 & 1.7 & 4.06 \\
\hline $18: 1 n-9$ & 7.1 & 8.5 & 12.4 & 15.5 & 17.2 & 5.23 \\
\hline 18:1n-7 & 2.3 & 1.3 & 3.5 & & - & - \\
\hline $18: 2 n-6$ & 1.5 & 1.8 & 1.9 & 1.0 & 1.7 & 1.03 \\
\hline $18: 3 n-3$ & 2.0 & 1.5 & - & 1.2 & 1.0 & 0.57 \\
\hline $18: 4 n-3$ & 0.8 & 0.6 & - & - & 3.6 & \\
\hline $20: 1 n-9$ & 1.2 & 1.7 & - & 0.3 & 4.4 & 2.87 \\
\hline $20: 4 n-6$ & 1.2 & 0.7 & - & 1.3 & 1.0 & 0.28 \\
\hline $20: 5 n-3$ & 10.7 & 7.8 & 12.4 & 6.9 & 12.4 & 28.2 \\
\hline $22: 1 n-11$ & 0.8 & 0.5 & 0.5 & - & - & - \\
\hline $22: 5 n-3$ & 1.1 & 0.6 & 1.7 & 0.8 & 0.7 & - \\
\hline $22: 6 n-3$ & 20.8 & 21.1 & 27.8 & 23.3 & 19.1 & 16.7 \\
\hline
\end{tabular}

a) Zlatanos and Laskaridis (2007); c) Ackman (2006); d) Nakamura et al. (2007); e) Lyberg and Adlercreutz (2008); f) Okada and Morrissey (2007).

Table 12. Comparison of wild and cultured sea bass (Dicentrarchus labrax) quality (adapted from Fuentes et al., 2010).

\begin{tabular}{|lccc|}
\hline Fatty acids (\%) & $\begin{array}{l}\text { Farmed wild sea bass } \\
\text { (Greece) }\end{array}$ & $\begin{array}{l}\text { Farmed wild sea bass } \\
\text { (Spain) }\end{array}$ & Wild sea bass \\
\hline $14: 0$ & 3.35 & 3.27 & 2.08 \\
\hline $15: 0$ & 0.73 & 0.59 & 0.92 \\
\hline $16: 0$ & 21.50 & 22.24 & 24.57 \\
\hline $17: 0$ & 0.29 & 0.24 & 0.50 \\
\hline $18: 0$ & 4.51 & 4.58 & 9.31 \\
\hline $16: 1 n-7$ & 4.19 & 4.58 & 5.12 \\
\hline $18: 1 n-9$ & 28.27 & 27.96 & 16.47 \\
\hline $20: 1 n-9$ & 4.01 & 5.66 & 1.95 \\
\hline $18: 2 n-6$ & 13.56 & 9.91 & 2.73 \\
\hline $18: 3 n-3$ & 1.15 & 1.19 & 1.13 \\
\hline $20: 2 n-6$ & 1.98 & 2.10 & 1.06 \\
\hline $20: 4 n-6$ & 0.33 & 0.48 & 5.37 \\
\hline $20: 5 n-3$ & 7.81 & 9.29 & 12.17 \\
\hline $22: 6 n-3$ & 8.33 & 7.36 & 16.62 \\
\hline
\end{tabular}

shown in table 15 and expressed as percentage of total fatty acids. They showed a concentration of approximately $16 \%-18 \%$ of saturated fatty acids (mainly 16:0), 35\% of MUFA (mainly $16: 1 n-7$ and $18: 1 n-9)$ and $34 \%-37 \%$ of PUFA. The total content of the $n-3$ derivatives EPA and DHA amounted to ca. $21 \%$ for the mullet eggs (Scano et al., 2008) and 31\% for the trout roes (Al-Sayed Mahmoud et al., 2008). The most common salmon roe products are ikura (salted individual eggs) and suijko (salted cured whole skeins), which are produced mainly from chum salmon (Oncorhynchus keta) and pink salmon (Oncorhynchus gorbuscha).

Bekhit et al. (2009) have studied the physicochemical properties of chinook salmon and their impact on the maturity. Fish oils play an important role in providing the energy required by the eggs during development. Palmitic acid (16:0) was the dominant saturated fatty acid in salmon roe. Similarly, oleic acid was the most abundant monounstaturated fatty acid. EPA and DHA are the dominant polyunsaturated fatty acids with $6.8 \%$ and $24.3 \%$ of total fatty acid composition, respectively. However, maturity had no effect on the percentage of the fatty acids. Lipids 
Table 13. Fatty acids composition from liver and muscle of three Mauritanian rays (adapted from Vall Ould El Kebir et al. 2007).

\begin{tabular}{|c|c|c|c|c|}
\hline \multirow[t]{2}{*}{ Fatty acids } & \multicolumn{2}{|c|}{ Dasyatis marmorata } & \multicolumn{2}{|c|}{ Rhinobatos cemiculus } \\
\hline & Muscle & Liver & Muscle & Liver \\
\hline $14: 0$ & 2.24 & 5.77 & 5.83 & 0.05 \\
\hline 15:0 & 0.29 & 0.18 & 0.43 & 0.12 \\
\hline $16: 0$ & 19.4 & 14.10 & 21.0 & 20.7 \\
\hline $\mathrm{i}-17: 0$ & 0.98 & 0.32 & 0.73 & 0.37 \\
\hline ai-17:0 & 0.22 & 0.37 & 0.45 & 0.06 \\
\hline $17: 0$ & 0.18 & 0.27 & 0.41 & 0.19 \\
\hline 18:0 & 9.23 & 5.51 & 13.3 & 19.4 \\
\hline $20: 0$ & 0.21 & 0.11 & 0.13 & 0.23 \\
\hline $22: 0$ & 0.42 & - & 0.60 & - \\
\hline $16: 1 n-10$ & 0.34 & 0.58 & 0.28 & 0.24 \\
\hline $16: 1 n-7$ & 2.85 & 11.6 & 1.90 & 9.42 \\
\hline $16: 1 n-6$ & 0.53 & 0.66 & 0.8 & 0.59 \\
\hline $17: 1 n-11$ & 0.68 & 0.11 & 0.26 & 0.87 \\
\hline $17: 1 n-8$ & 0.30 & 1.14 & 0.44 & 0.99 \\
\hline $18: 1 n-12$ & 1.48 & 1.18 & 1.81 & 0.13 \\
\hline 18:1n-9 & 8.61 & 6.59 & 8.00 & 6.54 \\
\hline 18:1n-7 & 3.49 & 5.63 & 0.44 & 0.35 \\
\hline $20: 1 n-10$ & 0.18 & - & 0.46 & - \\
\hline $20: 1 n-9$ & 0.50 & 1.02 & 0.21 & 0.61 \\
\hline $20: 1 n-7$ & 0.15 & 1.30 & 0.63 & 0.60 \\
\hline \multicolumn{5}{|c|}{ Diunsaturated fatty acids } \\
\hline $18: 2 \Delta 9,12$ & 1.09 & 1.08 & 0.40 & 0.39 \\
\hline $20: 2 \Delta 7,15$ & 0.80 & 1.86 & 0.43 & 1.30 \\
\hline $22: 2 \Delta 6,14$ & 0.19 & - & 0.23 & - \\
\hline $22: 2 \Delta 7,13$ & 3.46 & 2.20 & 2.28 & 1.94 \\
\hline $22: 2 \Delta 7,15$ & 3.46 & - & 0.35 & - \\
\hline $16: 3 n-4$ & 0.56 & 1.04 & 0.53 & 0.53 \\
\hline $18: 4 n-3$ & 0.67 & 1.15 & 0.68 & 0.81 \\
\hline $18: 3 n-6$ & 0.10 & 0.95 & 0.75 & 0.87 \\
\hline $20: 5 n-3$ & 4.95 & 3.41 & 4.63 & 5.01 \\
\hline $20: 4 n-6$ & 5.57 & 5.66 & 7.32 & 6.63 \\
\hline $22: 4 n-6$ & & 1.40 & - & 1.00 \\
\hline $22: 5 n-3$ & 9.37 & 5.24 & 3.91 & 4.76 \\
\hline $22: 6 n-3$ & 16.10 & 13.4 & 18.70 & 13.2 \\
\hline
\end{tabular}


Table 14. Fatty acid composition of liver oil of pelagic shark species of Carcharhinus falciformis from the Gulf of California and Caribbean waters (adapted from Navarro-Garcia et al., 2000).

\begin{tabular}{|lc|}
\hline Fatty acids & $\begin{array}{l}\text { Fatty acid profile } \\
\text { (weight percentage } \\
\text { of total fatty acids) }\end{array}$ \\
\hline $14: 0$ & 3.03 \\
\hline $14: 1$ & 0.97 \\
\hline $16: 0$ & 22.79 \\
\hline $16: 1$ & 3.48 \\
\hline $17: 0$ & 1.44 \\
\hline $17: 1$ & 0.66 \\
\hline $18: 0$ & 8.42 \\
\hline $18: 1 \mathrm{n}-9$ & 10.98 \\
\hline $18: 1 \mathrm{n}-7$ & 2.85 \\
\hline $18: 2$ & 1.33 \\
\hline $18: 3$ & 3.16 \\
\hline $20: 2$ & 0.66 \\
\hline $20: 4$ & 2.29 \\
\hline $20: 5$ & 5.14 \\
\hline $24: 1$ & 0.52 \\
\hline $22: 6$ & 25.05 \\
\hline
\end{tabular}

from spawning cod (G. morhua) roes were studied by Falch et al. (2006a) and results showed that more than $40 \%$ of the fatty acids were $n-3$ fatty acids. The polyunsaturated fatty acids made up nearly half of the amount of fatty acids and are comparable to what has recently been found in gonads of cod species (Falch et al., 2006b).

\section{Conclusion}

The standing stock of phytoplankton and zooplankton biomass represents the first link in the marine food chain for birds, fish, squid, seals and baleen whales. The fatty acids diversity (saturated, mono and polyunsaturated) esterified on TAG or on polar lipids classes of oil and fats appears as high energy reserve or provide buoyancy function (krill and deep-sea sharks). Marine oils are characterized by a high amount of long chain polyunsaturated n-3 fatty acids, namely EPA and DHA, which have considerable impacts on health. Since the epidemiological studies conducted by Bang and Dyerberg (1972), consumption of fish oil increases significantly due to the beneficial effects of these fatty acids related in numerous studies.

Table 15. Fatty acid composition of different source of fish roes (adapted from different authors).

\begin{tabular}{|llllll|}
\hline Fatty acid & $\begin{array}{l}\text { Chinook } \\
\text { salmon roe } \\
\text { (Oncorhynchus } \\
\text { tshawytscha) } \\
\text { (a) }\end{array}$ & $\begin{array}{l}\text { Pacific salmon } \\
\text { roe } \\
\text { (Oncorhynchus } \\
\text { keta) } \\
\text { (b) }\end{array}$ & $\begin{array}{l}\text { Trout roe } \\
\text { (Oncorhynchus } \\
\text { mykiss) } \\
\text { (c) }\end{array}$ & $\begin{array}{l}\text { cod } \\
\text { (G. Morhua) } \\
\text { (d) }\end{array}$ & $\begin{array}{l}\text { mullet roe } \\
\text { (Mugil } \\
\text { cephalus) } \\
\text { (e) }\end{array}$ \\
\hline $14: 0$ & 1.54 & 3.19 & 3.0 & 2.4 & 2.07 \\
\hline $15: 0$ & 0.35 & 0.56 & 0.2 & - & 0.44 \\
\hline $16: 0$ & 11.65 & 11.53 & 16.1 & 17.9 & 10.90 \\
\hline $16: 1 n-7$ & 4.54 & 5.45 & 6.2 & 3.7 & 17.92 \\
\hline $18: 0$ & 4.32 & 3.60 & 5.1 & 1.3 & 3.18 \\
\hline $18: 1 \mathrm{n}-7$ & 3.25 & 2.44 & 4.3 & 13.0 & 7.22 \\
\hline $18: 1 \mathrm{n}-9$ & 22.33 & 16.21 & 15.6 & 2.7 & 10.61 \\
\hline $18: 2 \mathrm{n}-6$ & 3.42 & 1.59 & 4.2 & 0.8 & 1.27 \\
\hline $18: 3 \mathrm{n}-3$ & 0.6 & 1.20 & 1.1 & 0.5 & 0.57 \\
\hline $20: 4 \mathrm{n}-6$ & 2.40 & 1.37 & 1.3 & 1.4 & 1.69 \\
\hline $20: 5 \mathrm{n}-3$ & 6.86 & 16.33 & 11.5 & 14.6 & 9.40 \\
\hline $22: 5 \mathrm{n}-5$ & 3.85 & 4.37 & 4.8 & 1.3 & 5.95 \\
\hline $22: 6 \mathrm{n}-3$ & 24.32 & 16.87 & 24.0 & 29.5 & 11.62 \\
\hline
\end{tabular}

During the 1980s, lipids researches focused on the beneficial EPA effects on heart and inflammatory diseases. And in 1990s, health beneficial effects of the DHA were found - the neonatal development, brain development and eyesight. Today, cognitive decline in the elderly is a major healthcare concern, and effects of these PUFAs, mainly the DHA were explored to treat or delay the onset of the Alzheimer's disease (AD) (Cunnane et al., 2009). Weekly fish consumption is today recommended by many authorities, and world fish captures steadily grow (FAO, 2009). However, fish species stock will not be sufficient to answer consumer's demand. In addition, aquaculture production is playing an increasing role in satisfying demand for human consumption of fish and fishery products. The consumption rose from $14 \%$ in 1986, to $30 \%$ in 1996 and to $47 \%$ in 2006, and it can be expected to reach $50 \%$ in the next few years (FAO, 2009). In farmed fish, artificial diets provide a wide range of nutrients, which not only determine fish growth rate but also flesh composition in particular the lipid content, which may be quantitatively and qualitatively modified. Sustainable expansion of aquaculture requires the use of alternative lipid sources e.g. vegetable oils, but modified feed formulations may alter the final fatty acid composition, mainly the LC-PUFA content of cultured products, and limit their nutritional value to human consumers.

In recent year, marine $\mathrm{PL}$ with the high content of LC-PUFA represent a potential EPA and DHA source for human consumption. Today, there are no rich sources on marine-based PL. Small commercial production of these lipids was extracted from krill, fish roes, salmon heads and squid. These polar lipids were commonly used in formulas for fish larvae in aquaculture. PL applications as functional foods, dietary supplements will become very important in the near future with nano-structured drug carriers in pharmaceutical and biomedical areas.

\section{REFERENCES}

Ackman RG. Fish lipids. Part 1. In: Connell J), ed. Advances in Fish Science and Technology. 1980.

AFSSA. Avis de l'Agence française de sécurité sanitaire des aliments relatif à l'actualisation des apports nutritionnels conseillés pour les acides gras (mars 2010).

Alkanani T, Parrish CC, Thompson Rl, McKenzie $\mathrm{CH}$. Role of fatty acids in cultured mussels, Mytilus edulis, grown in Notre Dame Bay, Newfoundland. J Exp Mar Biol Ecol 2007; 348: 33-45.

Al-Sayed Mahmoud K, Linder M, Fanni J, Parmentier M. Characterisation of the lipid fractions obtained by proteolytic and chemical extractions from rainbow trout (Oncorhynchus mykiss) roe. Process Biochem 2008; 43: 376-83. 
Aubourg SP, Medina I, Pérez-Martin R. Polyunsaturated fatty acids in tuna phospholipids: Distribution in the sn-2 location and changes during cooking. J Agric Food Chem 1996; 44: 585-9.

Aursand M, Jorgensen L, Grasdalen H. Positional Distribution of 03 fatty acids in marine lipid triacylglycerols by high-resolution $13 \mathrm{C}$ nuclear magnetic resonance spectroscopy. I Am Oil Chem Soc 1995; 72: 293-7.

Aursand M, Mabon F, Martin G). Characterization of farmed and wild salmon (Salmo salar) by a combined use of compositional and isotopic analyses. I Am Oil Chem Soc 2000; 77: 659-66.

Bang H, Dyerberg J. Plasma lipids and lipoproteins in Greenlandic West Coast Eskimos. Acta Med Scand 1972; 192: 85-94.

Bekhit A, Morton JD, Dawson CO, Zhao JH, Lee H. Impact of maturity on the physicochemical and biochemical properties of chinook salmon roe. Food Chem 2009; 117: 318-25.

Belhaj N, Arab-Tehrany E, Linder M. Oxidative kinetics of salmon oil in bulk and in nanoemulsion stabilized by marine lecithin. Process Biochem 2010; 45: 187-95.

Brockerhoff H, Hoyle R, Hwang P, Litchfield C. Positional distribution of fatty acids in depot triglycerides of aquatic animals. Lipids 1967; 3: 24-9.

Budge SM, Springer AM, Iverson SJ, Sheffield G, Rosa C. Blubber fatty acid composition of bowhead whales, Balaena mysticetus: Implications for diet assessment and ecosystem monitoring. J Exp Mar Biol Ecol 2008; 359: 40-6.

Cunnane SC, Plourde M, Pifferi F, Bégin M, Féart C, Barberger-Gateau P. Review: Fish, docosahexaenoic acid and Alzheimer's disease. Prog Lipid Res 2009; 48: 239-56.

Falch E, Rustad T, Aursand M. By-products from gadiform species as a raw material for production of marine lipids as an ingredient for food and feed. Process Biochem 2006a; 41: 666-74.

Falch E, Størseth TR, Aursand M. Multi-component analysis of marine lipids in fish gonads with emphasis on phospholipids using high resolution NMR spectroscopy. Chem Phys Lipids 2006b; 144: 4-16.

Fuentes A, Fernández-Segovia I, Serra JA, Barat JM. Comparison of wild and cultured sea bass (Dicentrarchus labrax) quality. Food Chem 2010; 119: 1514-8.

Giogios I, Grigorakis K, Nengas I, Papasolomontos S, Papaioannoub N, Alexis MN. Fatty acid composition and volatile compounds of selected marine oils and meals. / Sci Food Agric 2009; 89: 88-100.
Hagen W, Auel H. Seasonal adaptations and the role of lipids in oceanic zooplankton. Zoology 2001; 104: 313-26.

Hagen W, Van Vleet ES, Kattner G. Seasonal lipid storage as overwintering strategy of Antarctic krill. Mar Ecol Prog Ser 1996; 134: 85-9.

Horrocks LA, Yeo YK. Health benefits of docosahexaenoic acid. Pharm Res 1999; 40: 211-25.

Jensen $\mathrm{KN}$, Jacobsen C, Nielsen H. Fatty acid composition of herring (Clupea harengus L.): influence of time and place of catch on n-3 PUFA content. / Sci Food Agric 2007; 87: 710-8.

Ju SJ, Harvey H. Lipids as markers of nutritional condition and diet in the Antarctic krill Euphausia superba and Euphausia crystallorophias during austral winter. Deep-Sea Res II 2004; 51: 2199-214.

Lane RL, Jesse T, Trushenski JT, Kohler CC. Modification of Fillet Composition and Evidence of Differential Fatty Acid Turnover in Sunshine BassMorone chrysops $\times M$. saxatilis Following Change in Dietary Lipid Source. Lipids 2006; 41: 1029-38.

Leblond JD, Chapman PJ. Lipid class distribution of highly unsaturated long chain fatty acids in marine dinoflagellates. J Phycol 2000; 36: 1103-8.

Linder M, Fanni J, Parmentier M. Proteolytic Extraction of Salmon Oil and PUFA Concentration by Lipases. Mar Biotechnol 2005; 15: 70-6.

Nanton DA, Vegusdal A, Bencze Rørå AM, et al. Muscle lipid storage pattern, composition, and adipocyte distribution in different parts of Atlantic salmon (Salmo salar) fed fish oil and vegetable oil. Aquaculture 2007; 265: 230-43.

Navarro-Garcia G, Pacheco-Aguilar R, VallejoCordova B, Ramirez-Suarez JC, Bolanos A. Lipid composition of the liver oil of shark species from the Caribbean and Gulf of California waters. J Food Comp Anal 2000; 13: 791-8.

Nwosu CV, Boyd LC. Positional distribution of fatty acids on triacylglycerols of menhaden (Brevoortia tyrannis) and salmon (Salmo salar) oils. J Food Lipids 1997; 4: 65-74.

Parrish CC, DeFritas AS, Bodennec G, MacPherson EJ, Ackman R. Lipid composition of the toxic marine diatom Nitzschis pungens. Phytochemistry 1991; 30: 113-6.

Perez-Velazquez M, Gonza'lez-Felix ML, NavarroGarcia G, Valenzuela-Escalante E. Nutritional Value of Various Ray Fish Liver Oils to the Pacific White Shrimp Litopenaeus vannamei. Lipids 2008; 43: 1009-16.

Phleger CF, Nichols PD, Virtue P. Lipids and trophodynamics of Antarctic zooplankton. Comp Biochem Physiol Part B 1998; 120: 311-23.
Polvi SL, Ackman RG. Atlantic salmon (Salmo salar) muscle lipids and their response to alternative dietary fatty acid source. J Agric Food Chem 1992; 40: 1001-7.

Riediger ND, Othman RA, Suh MRD, Moghadasian MH. A Systemic Review of the Roles of n-3 Fatty Acids in Health and Disease. Journal of the American Dietetic Association 2009; 109, 668-679.

Robin JH, Regost C, Arzela J, Kaushik S. Fatty acid profile of fish following a change in dietary fatty acid source: model of fatty acid composition with a dilution hypothesis. Aquaculture 2003; 225: 283-93.

Scano P, Rosa A, Cesare Marincola F, et al. 13C NMR, GC and HPLC characterization of lipid components of the salted and dried mullet (Mugil cephalus) roe "bottarga". Chem Phys Lipids 2008; 151: 69-76.

Simopoulos A. Omega-3 fatty acids in health and disease and in growth and development. Am / Clin Nutri 1991; 54: 438-63.

Sirot V, Oseredczuk M, Bemrah-Aouachria N, Volatier JL, Leblanc JC. Lipid and fatty acid composition of fish and seafood consumed in France: CALIPSO study. I Food Compost Anal 2008; 21: 8-16.

Soriguer F, Serna S, Valverde E, et al. Lipid, protein and calorie content of different Atlantic and Mediterranean fish, shellfish and mollusks commonly eaten in the south of Spain. Eur / Epidemio 1997a; 13: 451-63.

Soriguer F, Serna S, Valverde E, et al. Lipid, protein, and calorie of different Atlantic and Mediterranean fish, shellfish, molluscs commonly eaten in the south of Spain. Eur J Epidemio 1997b; 13: 451-63.

Stansby ME. 1969. World review of Nutrition and Dietetics. New York : Karger, Basel, 1969.

Takahashi K. Medical applications of fisheries by-products. In: Sakaguchi, M. (Ed.), More Efficient Utilization of Fish and Fisheries Products. Dev Food Sci 2004; vol. 42. Elsevier Ltd., Oxford, UK, pp. 87-96.

The State of World Fisheries and Aquaculture 2008. FAO Fisheries and Aquaculture. Rome: Food and Agriculture Organization of the United Nations, 2009.

Watkins $C$. Krill oil: next generation source of omega3s? Inform 2007; 18: 588-92.

Wetherbee BM, Peter D, Nichols P. Lipid composition of the liver oil of deep-sea sharks from the Chatham Rise, New Zealand. Comp Biochem Physiol Part B 2000; 125: 511-21.

Zlatanos S, Laskaridis K. Seasonal variation in the fatty acid composition of three Mediterranean fish - sardine (Sardina pilchardus), anchovy (Engraulis encrasicholus) and picarel (Spicara smaris). Food Chem 2007; 103: $725-8$. 